Blood Purif 1994;12:3-4

\title{
Contents, Vol. 12, No. 1, 1994
}

\section{Scherbenske, M.J. Striker, G.E. ; Blantz, R.C; Editorial 5}

Nissenson, A.R. Erythropoietin Overview - 19936

Aronoff, G.; Brater, D.C.; Sçhrier, R.; Bennett, W.M. Use of Drugs in Patients with Renal Insufficiency. Workshop Report 14

Kaplan, R.M.; Mehta, R. Outcome Measurement in Kidney Disease 20

Blantz, R.C. Vascular Biology: Relevance of Nitric Oxide in Vascular and Nonvascular

Tissue with Normal and Decreased Renal Function 30

Kelly, C.J. T Cell Function in Chronic Renal Failure and Dialysis 36

Cheung, A.K. Quantitation of Dialysis. The Importance of Membrane and Middle Molecules 42

Vlassara, H. Serum Advanced Glycosylation End Products: A New Class of Uremiç Toxins? 54

Kaysen, G.A. Hyperlipidemia of Chronic Renal Failure 60

Harrison, J.E.; McNeill, K.G. Nutritional Assessment

3

Johansen, K.; Lyman, D.; $\quad$ Biomaterials for Hemodialysis Access

Sauvage, L.

Wilson, R.A.; Norman, D J.; Noninvasive Cardiac Testing in the End-Stage Renal

Barry, J.M.; Bennett, W.M. Disease Patient

Author Index 84

Subject Index 84

4

Contents 